\title{
FAKTOR DETERMINAN TERJADINYA BURNOUT PADA PERAWAT DI RSUD LAMADUKKELLENG KABUPATEN WAJO
}

\author{
Rosnania \\ Pendidikan Profesi Ners, Universitas Megarezky \\ Jl. Antang Raya No.4, Makassar, 90234 \\ E-mail : inna.psmik.unhas2012@gmail.com
}

\begin{abstract}
ABSTRAK
Burnout merupakan kumpulan gejala yang muncul akibat penggunaan energi melebihi sumber daya seseorang sehingga mengakibatkan munculnya kelelahan fisik, emosional dan mental. Penelitian ini bertujuan untuk mengetahui faktor determinan terjadinya burnout pada perawat. Desain penelitian yang digunakan adalah Cross Sectional. Penelitian dilaksanakan di Ruang Rawat Inap RSUD Lamaddukkelleng Kabupaten Wajo. Pengambilan sampel menggunakan teknik purposive sampling dengan jumlah sampel sebanyak 100 orang. Data dikumpulkan dengan menggunakan kuesioner. Hasil penelitian dengan menggunakan uji chi square menunjukkan bahwa faktor instrinsik $(\alpha=0,074)$ dan kepemimpinan $(\alpha=$ $0,286)$ tidak berhubungan dengan terjadinya burnout pada perawat, sedangkan variabel organisasi $(\alpha=0,009)$, reward $(\alpha=$ $0,002)$, dan SDM $(\alpha=0,017)$ berhubungan dengan terjadinya burnout pada perawat. Hasil uji Logistic Regression menunjukkan reward merupakan faktor yang paling dominan berhubungan dengan terjadinya burnout pada perawat. Kesimpulan : variabel organisasi, reward dan SDM adalah faktor determinan terjadinya burnout pada perawat di RSUD Lamddukkelleng Kabupaten Wajo.
\end{abstract}

Kata Kunci: Burnout Perawat, Faktor Instrinsik, Variabel Organisasi, Reward, SDM, Kepemipinan

\section{PENDAHULUAN}

Burnout merupakan kumpulan gejala yang muncul akibat penggunaan energi yang melebihi sumber daya seseorang sehingga mengakibatkan munculnya kelelahan fisik, emosional dan mental (Thyer et al., 2018). Konteks tentang burnout muncul dalam pelayanan pelanggan (human service) seperti tenaga perawat, pekerja sosial, perusahaan jasa, bidang pendidikan dan lain lain yang berkaitan dengan layanan yang melibatkan interaksi antar personal yang mengakibatkan munculnya ketiga gejala burnout (Leiter \& Maslach, 2016). Perawat sering dihadapkan pada kondisi upaya menyelamatkan pasien, mengerjakan tugas rutinitas, ruang kerja yang sumpek, jumlah pasien yang banyak, dan harus bertindak cepat dalam menangani kebutuhan pasien. Banyaknya jumlah pasien yang dirawat dan semakin beragamnya penyakit merupakan stresor kerja bagi perawat. Stressor kerja yang tidak dapat diadaptasi dan berlangsung dalam jangka waktu yang lama dengan intensitas yang cukup tinggi inilah yang disebut dengan burnout (Avila et al., 2021).

Kecenderungan burnout yang dialami perawat dalam bekerja akan sangat mempengaruhi kualitas pelayanan keperawatan yang diberikan kepada pasien, serta dapat menyebabkan efektifitas pekerjaan menurun, hubungan sosial antar rekan kerja menjadi renggang dan timbul perasaan negatif terhadap pasien, pekerjaan, dan tempat kerja perawat. Dengan demikian, gejala yang menunjukkan adanya kecenderungan burnout yang dialami oleh perawat perlu mendapatkan perhatian yang cukup serius dari pihak terkait, dalam hal ini manajemen rumah sakit (Hidayat et al., 2021).

Menurut perawat, kejadian stress kerja yang berhubungan dengan burnout yang tinggi dipengaruhi oleh faktor seperti umur, lama kerja, posisi perawat, kurang adekuatnya jumlah staf, ketergantungan pasien, jenis kelamin dan tidak adekuatnya supervisi klinik. Faktor lainnya adalah beban kerja yang berlebihan, stress emosional, tidak ada evaluasi kinerja dan gaji rendah, kepemimpinan yang kurang baik, konflik dengan teman kerja, penerimaan terhadap tanggung jawab, kurang dukungan sosial, konflik dengan dokter, adanya stressor yang berhubungan dengan kehidupan pribadi, merasa pekerjaan adalah ancaman dan tingginya tuntutan keperawatan (Lasebikan \& Oyetunde, 2017).

Perawat yang mengalami burnout akan cenderung bersikap sinis terhadap orang lain dan pasien, merasa lelah sepanjang waktu, merasa tidak mampu melakukan pekerjaan dengan benar dan mulai enggan bekerja. Pada kondisi yang sudah parah akan muncul keinginan untuk beralih ke profesi lain. Padahal profesi perawat yang dinamis dan menuntut keterlibatan kerja yang mendalam. Jika perawat mengalami burnout, tentu saja akan menghambat yang kinerja perawat dan menjadi tidak selaras dengan visi dan misi rumah sakit dalam meningkatkan kualitas pelayanan keperawatan.

Perawat di instalasi rawat inap dituntut memiliki kondisi yang baik untuk dapat menyelesaikan tugasnya terkait jadwal kerja yang padat (shift 24 jam). Meningkatnya kelelahan dapat memicu menurunnya kinerja. Kelelahan yang muncul dapat disebabkan oleh 
adanya peningkatan tuntutan kerja yang menuntut perawat untuk bekerja secara maksimal dan professional (Asi, 2016).

Hasil penelitian yang dilakukan oleh Lasebikan \& Oyetunde (Lasebikan \& Oyetunde, 2017) di Rumah Sakit Umum Nigeria menunjukkan bahwa tingkat burnout pada perawat sangat tinggi yaitu $39,1 \%$ yang mengalami kelelahan emosional, 29,2\% mengalami depersonalisasi dan $40 \%$ mengalami rendahnya penghargaan terhadap diri. Sedangkan hasil penelitian yang dilakukan Eliyana (Eliyana, 2018) di RSJ Kalimantan Barat menunjukkan bahwa burnout perawat pelaksana dalam kategori rendah sebesar $82,8 \%$ dan kategori sedang sebesar 17,2\% serta variabel yang paling dominan dengan burnout adalah variabel beban kerja.

Hasil penelitian Wardah \& Tampubolon (Wardah \& Tampubolon, 2021) di Rumah Sakit Santa Maria Pekanbaru menunjukkan bahwa Tidak terdapat hubungan antara stres kerja $(\mathrm{p}=0,387)$ dengan kejadian Burnout. Sedangkan hasil penelitian yang dilakukan oleh Ramdan \& Fadly (Ramdan \& Fadly, 2016) menunjukkan bahwa Dukungan keluarga mempunyai pengaruh yang paling besar terhadap burnout perawat (nilai OR 17.87), disusul dengan variabel kepemimpinan (nilai OR 14.92) dan beban kerja (nilai OR 2.36).

Hasil penelitian yang dilakukan Wirati, Wati \& Saraswati (Wirati et al., 2020) menunjukkan bahwa motivasi kerja kuat sebanyak 95 orang $(57,6 \%)$, sebagian besar perawat mengalami burnout sedang sebanyak 85 orang $(51,5 \%)$ dan ada hubungan burnout dengan motivasi kerja perawat pelaksana $(\mathrm{p}=0,000)$. Nilai kekuatan korelasi 0,406 (kekuatan sedang) dan arah korelasi negatif yang artinya apabila tingkat burnout rendah maka motivasi kerja kuat.

Hasil wawancara dengan beberapa perawat mengatakan bahwa masalah-masalah yang sering terjadi adalah mereka bertindak tanpa berpikir, terlalu tegang karena diwajibkan mengikuti apel pagi dan siang serta mengisi absen tiap jam sehingga sulit berkonsentrasi terhadap pekerjaan, menganggap kondisi pasien sudah biasa, tidak peduli dengan kebutuhan pasien, bersikap kasar terhadap orang lain, melemparkan tugas dan tanggung jawab kepada orang lain, kurang peduli dengan perkembangan pasien, sering terlambat dan bolos kerja, malas bekerja, tidak ada penghargaan kepada perawat yang berprestasi dan sebaliknya tidak ada teguran bagi perawat yang melakukan kesalahan akibatnya perawat kurang bersungguh-sungguh dalam melakukan pekerjaannya.

Munculnya kejadian burnout merupakan indikasi adanya masalah yang mendasar dalam organisasi tersebut, oleh karena itu perlu adanya upaya untuk mengeksplorasi faktor yang berhubungan dengan kejadian burnout perawat sehingga organisasi dapat menekannya sampai ke tingkat wajar. Menurut kepala seksi keperawatan belum pernah dilakukan penelitian tentang burnout pada perawat di lingkungan rumah sakit.
Burnout yang tinggi menyebabkan kinerja menjadi tidak optimal, akibatnya pelayanan kesehatan di rumah sakit menjadi tidak optimal pula. Berdasarkan hal tersebut maka fokus dari penelitian ini adalah untuk mengetahui "faktor determinan terjadinya burnout pada perawat di RSUD Lamddukkelleng Kabupaten Wajo”.

\section{RUANG LINGKUP}

Penelitian ini dilaksanakan di Rumah Sakit Umum Daerah Lamaddukkelleng Kabupaten Wajo pada ruang rawat inap yaitu ruangan VIP 1, Bedah Umum, Interna Umum, Interna Sayra, Bedah Sayra, Anak Sayra, Anak Umum, Perinatologi, dan Vip II. Adapun faktor-faktor determinan terjadinya burnout yang diteliti terbatas pada faktor instrinsik yaitu karakteristik pekerjaaan dan otonomi, variabel organisasi yaitu beban kerja, insentif dan kebijakan organisasi, sistem reward (penghargaan), sistem sumber daya manusia yaitu jumlah tenaga dan pengembangan staf serta kepemimpinan yaitu supervisi dan komunikasi.

\section{BAHAN DAN METODE}

Penelitian ini dilaksanakan di Ruang Rawat Inap RSUD Lamaddukkelleng Kabupaten Wajo pada bulan februari 2021 selama 3 minggu dengan metode penelitian sebagai berikut :

\subsection{Desain Penelitian, Populasi dan Sampel}

Desain Penelitian yang digunakan adalah Cross Sectional. Populasi adalah semua perawat pelaksana yang bertugas di ruang rawat inap RSUD Kabupaten Wajo yang berjumlah 133 orang. Sampel sebanyak 100 orang yang dipilih secara purpossive sampling.

\subsection{Metode Pengumpulan Data dan Analisa Data}

Pengumpulan data dilakukan dengan menggunakan kuesioner. Kuesioner burnout mengacu pada Maslach Burnout Inventory (Leiter \& Maslach, 2016), yang disusun dan dikembangkan sendiri oleh peneliti yang mengacu teori Whitehead et al (Grigor, 2018), yang sebelumnya dilakukan uji validitas dan realibilitas.

Data dianalisis secara univariat untuk melihat distribusi frekuensi setiap variabel. Untuk analisis bivariat digunakan uji chi square untuk melihat adanya hubungan antara variabel independen dengan variabel dependen dengan tingkat signifikansi $p<0,05$. Untuk multivariat digunakan uji logistic regression untuk melihat variabel yang paling dominan berhubungan dengan burnout pada perawat. Adapun alur penelitian dapat dilihat pada gambar 1 . 


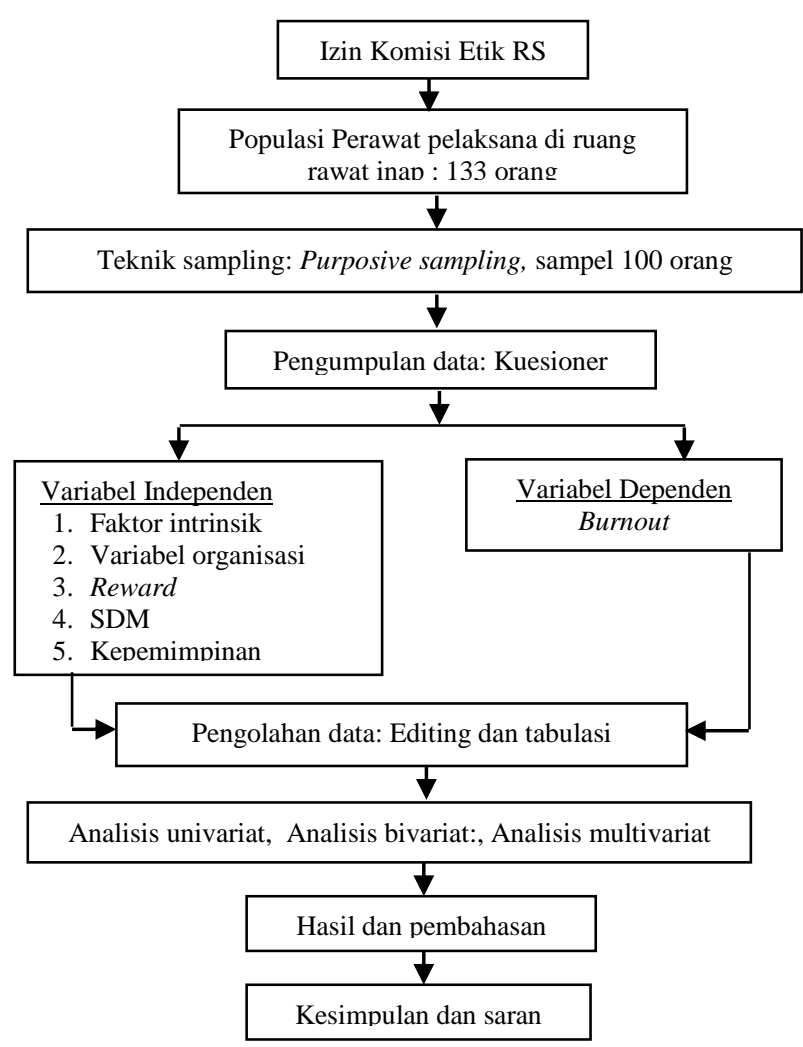

Gambar 1. Skema Alur Penelitian

\section{PEMBAHASAN}

Data pada penelitian ini diolah dan dianalisis menggunakan uji Chi-Square Test. Hasil analisis data disajikan dalam bentuk tabel yang dilengkapi dengan penjelasan sebagai berikut :

\subsection{Analisis Univariat}

Tabel 1 menunjukkan bahwa dari 100 perawat yang diteliti, yang puas dengan faktor intrinsik sebanyak $97 \%$ dan yang tidak puas sebanyak $3 \%$.

\section{Tabel 1. Distribusi Faktor Instrinsik}

\begin{tabular}{|l|c|c|}
\hline \multicolumn{1}{|c|}{ Faktor Intrinsik } & $\mathrm{n}$ & $\%$ \\
\hline Tidak Puas & 3 & 3.0 \\
\hline Puas & 97 & 97.0 \\
\hline Total & 100 & 100.0 \\
\hline
\end{tabular}

Faktor instrinsik adalah faktor yang berasal dari pekerjaan itu sendiri. Faktor instrinsik terdiri dari dua sub variabel yaitu karakteristik pekerjaan dan otonomi. Karakteristik pekerjaan adalah atribut-atribut tugas yang memiliki sifat penting khusus. Sedangkan otonomi perawat adalah perawat bekerja dengan keilmuannya sendiri dalam merawat pasien tidak tergantung pada instruksi dokter dalam bekerja. Berdasarkan kedua sub variabel tersebut lebih banyak perawat yang puas daripada yang tidak puas.
Tabel 2 menunjukkan bahwa dari 100 perawat yang diteliti, yang tidak puas dengan variabel organisasi sebanyak $74 \%$ dan yang puas sebanyak $26 \%$.

Tabel 2. Distribusi Variabel Organisasi

\begin{tabular}{|l|c|c|}
\hline \multicolumn{1}{|c|}{ Variabel Organisasi } & $\mathrm{n}$ & $\%$ \\
\hline Tidak Puas & 74 & 74.0 \\
\hline Puas & 26 & 26.0 \\
\hline Total & 100 & 100.0 \\
\hline
\end{tabular}

Variabel organisasi terdiri dari tiga sub variabel yaitu beban kerja, insentif dan kebijakan organisasi. Beban kerja perawat adalah seluruh kegiatan/aktivitas yang dilakukan seorang perawat selama bertugas di suatu unit pelayanan keperawatan. Insentif adalah salah satu bentuk penghasilan atau imbalan langsung yang berupa balas jasa diluar gaji tetap. Sedangkan kebijakan organisasi adalah tuntutan kegiatan secara umum dalam lingkup aktivitas organisasi. Berdasarkan sub variabel beban kerja menunjukkan lebih banyak perawat yang merasa puas, sedangkan untuk sub variabel insentif dan kebijakan organisasi lebih banyak perawat yang tidak puas.

Tabel 3 menunjukkan bahwa dari 100 perawat yang diteliti, yang tidak puas dengan reward sebanyak $69 \%$ dan yang puas sebanyak $31 \%$.

Tabel 3. Distribusi Reward

\begin{tabular}{|l|c|c|}
\hline \multicolumn{1}{|c|}{ Reward } & $\mathrm{n}$ & $\%$ \\
\hline Tidak Puas & 69 & 69.0 \\
\hline Puas & 31 & 31.0 \\
\hline Total & 100 & 100.0 \\
\hline
\end{tabular}

Reward merupakan penghargaan yang diberikan atasan kepada karyawannya atas kinerja yang telah dicapai. Reward dapat bersifat finansial (pemberian uang dan hadiah) dan non finansial (ucapan terima kasih, pujian, isi kerja dan lingkungan kerja). Pemberian reward sesuai pekerjaan menjadi salah satu faktor pendorong semangat dalam bekerja. Berdasarkan Faktor reward menunjukkan bahwa lebih banyak perawat yang tidak puas daripada yang puas.

Tabel 4 menunjukkan bahwa dari 100 perawat yang diteliti, yang puas dengan SDM sebanyak 51\% dan yang tidak puas sebanyak $49 \%$.

Tabel 4. Distribusi Sumber Daya Manusia

\begin{tabular}{|l|c|c|}
\hline \multicolumn{1}{|c|}{ Sumber Daya Manusia } & $\mathrm{n}$ & $\%$ \\
\hline Tidak Puas & 49 & 49.0 \\
\hline Puas & 51 & 51.0 \\
\hline Total & 100 & 100.0 \\
\hline
\end{tabular}

Faktor Sumber Daya Manusia terdiri dari dua sub variabel yaitu jumlah tenaga dan pengembangan staf. Jumlah tenaga keperawatan harus disesuaikan dengan kebutuhan dan tujuan pelayanan. Sedangkan 
pengembangan staf adalah membantu perawat untuk meningkatkan diri dalam pengetahuan, keterampilan dan pengalaman dibidangnya. Berdasarkan kedua sub variabel tersebut menunjukkan jumlah yang hampir sama antara yang puas dan yang tidak puas.

Tabel 5 menunjukkan bahwa dari 100 perawat yang diteliti, yang puas dengan kepemimpinan sebanyak $78 \%$ dan yang tidak puas sebanyak $22 \%$.

Tabel 5. Distribusi Kepemimpinan

\begin{tabular}{|l|c|c|}
\hline \multicolumn{1}{|c|}{ Kepemimpinan } & $\mathrm{n}$ & $\%$ \\
\hline Tidak Puas & 22 & 22.0 \\
\hline Puas & 78 & 78.0 \\
\hline Total & 100 & 100.0 \\
\hline
\end{tabular}

Faktor kepemimpinan terdiri dari dua sub variabel yaitu supervisi dan komunikasi. Supervisi adalah pengamatan atau pengawasan secara langsung terhadap pelaksanaan pekerjaan. Sedangkan komunikasi merupakan proses penyampain informasi dari satu pihak kepada pihak lain. Berdasarkan kedua sub variabel tersebut menunjukkan lebih banyak perawat yang puas dari pada yang tidak puas.

Tabel 6 menunjukkan bahwa dari 100 perawat yang diteliti, yang mengalami burnout rendah sebanyak 51\%, burnout sedang sebanyak $49 \%$ dan tidak ada yang mengalami burnout tinggi (0\%).

Tabel 6. Distribusi Tingkat Burnout

\begin{tabular}{|l|c|c|}
\hline \multicolumn{1}{|c|}{ Tingkat Burnout } & $\mathrm{n}$ & $\%$ \\
\hline Tinggi & 0 & 0.0 \\
\hline Sedang & 49 & 49.0 \\
\hline Rendah & 51 & 51.0 \\
\hline Total & 100 & 100.0 \\
\hline
\end{tabular}

\subsection{Analisis Bivariat}

Tabel 7 menunjukkan bahwa dari 49 perawat yang mengalami burnout sedang, yang merasa puas dengan faktor instrinsik sebanyak $46 \%$ dan yang tidak puas sebanyak 3\%. Sedangkan dari 51 perawat yang mengalami burnout rendah, semuanya merasa puas dengan faktor instrinsik.

Tabel 7. Hubungan Faktor Instrinsik dengan Burnout

\begin{tabular}{|l|c|c|c|c|c|c|c|}
\hline \multirow{2}{*}{$\begin{array}{l}\text { Faktor } \\
\text { Intrinsik }\end{array}$} & \multicolumn{6}{|c|}{ Tingkat Burnout } & \multirow{2}{*}{$\mathrm{p}$} \\
\cline { 2 - 7 } & \multicolumn{2}{|c|}{ Sedang } & \multicolumn{2}{|c|}{ Rendah } & \multicolumn{2}{|c|}{ Total } & \\
\cline { 2 - 7 } & $\mathrm{n}$ & $\%$ & $\mathrm{n}$ & $\%$ & $\mathrm{n}$ & $\%$ & \\
\hline $\begin{array}{l}\text { Tidak } \\
\text { Puas }\end{array}$ & 3 & 3.0 & 0 & 0.0 & 3 & 3.0 & \multirow{2}{*}{0.074} \\
\hline Puas & 46 & 46.0 & 51 & 51.0 & 97 & 97.0 & \\
\hline Total & 49 & 49.0 & 51 & 51.0 & 100 & 100.0 & \\
\hline
\end{tabular}

Hasil pengujian statistik dengan menggunakan ChiSquare Test menunjukkan bahwa nilai p (0.074) >0.05, ini berarti bahwa tidak ada hubungan antara faktor instrinsik dengan kejadian burnout pada perawat.
Tabel 8 menunjukkan bahwa dari 49 perawat yang mengalami burnout sedang, yang merasa tidak puas dengan variabel organisasi sebanyak $42 \%$ dan yang puas hanya $7 \%$. Sedangkan dari 51 perawat yang mengalami burnout rendah, yang merasa tidak puas dengan variabel organisasi sebanyak $32 \%$ dan yang puas sebanyak $19 \%$.

Tabel 8. Hubungan Variabel Organisasi dengan Burnout

\begin{tabular}{|l|c|c|c|c|c|c|c|}
\hline \multirow{2}{*}{$\begin{array}{l}\text { Variabel } \\
\text { Organisasi }\end{array}$} & \multicolumn{6}{|c|}{ Tingkat Burnout } & \multirow{2}{*}{$\mathrm{p}$} \\
\cline { 2 - 8 } & \multicolumn{2}{|c|}{ Sedang } & \multicolumn{2}{|c|}{ Rendah } & \multicolumn{2}{|c|}{ Total } & \\
\cline { 2 - 8 } & $\mathrm{n}$ & $\%$ & $\mathrm{n}$ & $\%$ & $\mathrm{n}$ & $\%$ & \\
\hline $\begin{array}{l}\text { Tidak } \\
\text { Puas }\end{array}$ & 42 & 42.0 & 32 & 32.0 & 74 & 74.0 & \multirow{2}{*}{0.009} \\
\hline Puas & 7 & 7.0 & 19 & 19.0 & 26 & 26.0 & \\
\hline Total & 49 & 49.0 & 51 & 51.0 & 100 & 100.0 & \\
\hline
\end{tabular}

Hasil pengujian statistik dengan menggunakan ChiSquare Test menunjukkan bahwa nilai p (0.009) < 0.05, ini berarti bahwa ada hubungan antara variabel organisasi dengan kejadian burnout pada perawat.

Tabel 9 menunjukkan bahwa dari 49 perawat yang mengalami burnout sedang, yang merasa tidak puas dengan reward sebanyak $41 \%$ dan yang puas hanya $8 \%$. Sedangkan dari 51 perawat yang mengalami burnout rendah, yang merasa tidak puas dengan reward sebanyak $28 \%$ dan yang puas sebanyak $23 \%$.

Tabel 9. Hubungan Reward dengan Burnout

\begin{tabular}{|l|c|c|c|c|c|c|c|}
\hline \multirow{2}{*}{ Reward } & \multicolumn{6}{|c|}{ Tingkat Burnout } & \multirow{2}{*}{$\mathrm{p}$} \\
\cline { 2 - 7 } & \multicolumn{2}{|c|}{ Sedang } & \multicolumn{2}{|c|}{ Rendah } & \multicolumn{2}{|c|}{ Total } & \\
\cline { 2 - 7 } & $\mathrm{n}$ & $\%$ & $\mathrm{n}$ & $\%$ & $\mathrm{n}$ & $\%$ & \\
\hline $\begin{array}{l}\text { Tidak } \\
\text { Puas }\end{array}$ & 41 & 41.0 & 28 & 28.0 & 69 & 69.0 & \multirow{2}{*}{0.002} \\
\hline Puas & 8 & 8.0 & 23 & 23.0 & 31 & 31.0 & \\
\hline Total & 49 & 49.0 & 51 & 51.0 & 100 & 100.0 & \\
\hline
\end{tabular}

Hasil pengujian statistik dengan menggunakan ChiSquare Test menunjukkan bahwa nilai $\mathrm{p}(0.002)<0.05$, ini berarti bahwa ada hubungan antara reward dengan kejadian burnout pada perawat.

Tabel 10 menunjukkan bahwa dari 49 perawat yang mengalami burnout sedang, yang merasa tidak puas dengan SDM sebanyak $30 \%$ dan yang puas sebanyak $19 \%$. Sedangkan dari 51 perawat yang mengalami burnout rendah, yang merasa puas dengan SDM sebanyak $32 \%$ dan yang tidak puas sebanyak $19 \%$. 
Tabel 10. Hubungan SDM dengan Burnout

\begin{tabular}{|l|c|c|c|c|c|c|c|}
\hline \multirow{2}{*}{ SDM } & \multicolumn{6}{|c|}{ Tingkat Burnout } & \multirow{2}{*}{$\mathrm{p}$} \\
\cline { 2 - 7 } & \multicolumn{2}{|c|}{ Sedang } & \multicolumn{2}{|c|}{ Rendah } & \multicolumn{2}{|c|}{ Total } & \\
\cline { 2 - 7 } & $\mathrm{n}$ & $\%$ & $\mathrm{n}$ & $\%$ & $\mathrm{n}$ & $\%$ & \\
\hline $\begin{array}{l}\text { Tidak } \\
\text { Puas }\end{array}$ & 30 & 30.0 & 19 & 19.0 & 49 & 49.0 & \multirow{2}{*}{0.017} \\
\hline Puas & 19 & 19.0 & 32 & 32.0 & 51 & 51.0 & \\
\hline Total & 49 & 49.0 & 51 & 51.0 & 100 & 100.0 & \\
\hline
\end{tabular}

Hasil pengujian statistik dengan menggunakan $\mathrm{Chi}$ Square Test menunjukkan bahwa nilai $\mathrm{p}(0.017)<0.05$, ini berarti bahwa ada hubungan antara SDM dengan kejadian burnout pada perawat.

Tabel 11 menunjukkan bahwa dari 49 perawat yang mengalami burnout sedang, yang merasa puas dengan kepemimpinan sebanyak $36 \%$ dan yang tidak puas sebanyak $13 \%$. Sedangkan dari 51 perawat yang mengalami burnout rendah, yang merasa puas dengan kepemimpinan sebanyak $42 \%$ dan yang tidak puas hanya $9 \%$.

Tabel 11. Hubungan Kepemimpinan dengan Burnout

\begin{tabular}{|l|c|c|c|c|c|c|c|}
\hline \multirow{2}{*}{$\begin{array}{l}\text { Kepemim } \\
\text { pinan }\end{array}$} & \multicolumn{6}{|c|}{ Tingkat Burnout } & \multirow{2}{*}{$\mathrm{p}$} \\
\cline { 2 - 7 } & \multicolumn{2}{|c|}{ Sedang } & \multicolumn{2}{|c|}{ Rendah } & \multicolumn{2}{|c|}{ Total } & \\
\cline { 2 - 7 } & $\mathrm{n}$ & $\%$ & $\mathrm{n}$ & $\%$ & $\mathrm{n}$ & $\%$ & \\
\hline $\begin{array}{l}\text { Tidak } \\
\text { Puas }\end{array}$ & 13 & 13.0 & 9 & 9.0 & 22 & 22.0 & \multirow{2}{*}{0.286} \\
\hline Puas & 36 & 36.0 & 42 & 42.0 & 78 & 78.0 & \\
\hline Total & 49 & 49.0 & 51 & 51.0 & 100 & 100.0 & \\
\hline
\end{tabular}

Hasil pengujian statistik dengan menggunakan $\mathrm{Chi}$ Square Test menunjukkan bahwa nilai $\mathrm{p}(0.286)>0.05$, ini berarti bahwa tidak ada hubungan antara kepemimpinan dengan kejadian burnout pada perawat.

\subsection{Analisis Multivariat}

Tabel 12 menunjukkan bahwa dari uji regresi logistic dari ketiga variabel independen yang berhubungan, maka variabel yang paling berpengaruh terhadap kejadian burnout adalah reward dengan nilai B $=1.000$.

Tabel 12. Uji Regresi Logistic

\begin{tabular}{|l|l|c|c|c|c|c|}
\hline No & $\begin{array}{l}\text { Variabel } \\
\text { Independen }\end{array}$ & B & Wald & df & Sig. & $\operatorname{Exp}(\mathrm{B})$ \\
\hline 1 & $\begin{array}{l}\text { Variabel } \\
\text { Organisasi }\end{array}$ & 0.777 & 2.025 & 1 & 0.155 & 2.174 \\
\hline 2 & Reward & 1.000 & 3.629 & 1 & 0.057 & 2.718 \\
\hline 3 & SDM & 0.552 & 1.502 & 1 & 0.220 & 2.737 \\
\hline
\end{tabular}

Penelitian ini menunjukkan tidak ada hubungan antara faktor instrinsik dengan burnout pada perawat. Hal ini disebabkan karena perawat menyadari tugas dan tanggung jawabnya sebagai perawat, di samping itu perawat merasa memiliki perasaan kompeten yang sama dalam menjalankan tugasnya. Dalam penelitian ini menggambarkan bahwa yang puas dengan faktor instrinsik jauh lebih besar daripada yang tidak puas tetapi mengalami burnout sedang, artinya bahwa faktor instrinsik tidak dapat mempengaruhi tingkat kejadian burnout pada perawat. Hal ini bertentangan dengan penelitian yang dilakukan oleh Lumbanraja \& Nizma (Lumbanraja \& Nizma, 2016), yang mengatakan bahwa pelatihan dan karakteristik pekerjaan yang terdiri dari signifikansi tugas, otonomi dan umpan balik secara serempak berpengaruh signifikan terhadap prestasi kerja perawat.

Penelitian ini menunjukkan bahwa ada hubungan antara variabel organisasi dengan tingkat burnout. Hal ini disebabkan karena perawat merasa tugasnya bukan hanya untuk merawat pasien tetapi juga untuk mengurus administrasi, kebersihan ruangan dan kadang-kadang mengurus pembagian makanan untuk pasien. Perawat juga merasa tidak puas karena jumlah insentif yang diterima tidak sebanding dengan pekerjaan yang dilakukan, disamping itu tidak ada standar dalam pembagian insentif, serta perawat merasa tidak puas karena aturan kerja yang terlalu ketat. Hal ini sesuai dengan penelitian lain yang dilakukan Suryani \& Wulandari (Suryani \& Wulandari, 2019), yang mengatakan bahwa beban kerja yang tinggi dapat menyebabkan perawat mengalami kelelahan atau kejenuhan. Hal ini akan berdampak pada penurunan kualitas pelayanan keperawatan yang dilakukan oleh perawat. Namun penelitian ini bertentangan dengan penelitian yang dilakukan oleh Wardana dkk (Wardana et al., 2017), yang mengatakan bahwa tidak ada hubungan antara pemberian insentif terhadap motivasi kerja perawat. Penelitian lain yang mendukung penelitian ini adalah penelitian yang dilakukan oleh Anik (Anik, 2013), yang mengatakan bahwa perawat yang kurang puas dengan kebijakan organisasi dan administrasi akan memiliki turnover intentions sebesar 7 kali lebih tinggi dibanding dengan perawat yang puas terhadap kebijakan organisasi dan administrasi.

Penelitian ini menunjukkan bahwa ada hubungan antara reward dengan tingkat burnout pada perawat. Hal ini disebabkan karena di rumah sakit belum dijalankan sistem reward dengan baik dan kriteria pemberian reward juga belum ada. Penelitian ini tidak sesuai dengan penelitian yang dilakukan oleh Rahayu \& Dewi (Rahayu \& Dewi, 2019), yang mengatakan bahwa tidak ada hubungan antara sistem reward dengan kinerja perawat dalam melaksanakan asuhan keperawatan. Namun penelitian ini sesuai dengan penelitian yang dilakukan oleh Kristianto \& Santoso (Kristianto \& Santoso, 2019), yang mengatakan bahwa ada hubungan antara pemberian reward ucapan terima kasih dengan kedisiplinan waktu perawat. Penelitian ini menunjukkan ada hubungan antara sistem SDM dengan tingkat burnout pada perawat.Hal ini disebabkan karena perawat merasa kurang puas dengan pengaturan jadwal dinas dan pihak rumah sakit jarang memberikan informasi tentang seminar, pelatihan dan beasiswa.Hasil penelitian ini sesuai dengan penelitian Kurnia dkk (Kurnia et al., 2018), yang mengatakan bahwa dengan perubahan 
jumlah tenaga, perawat dapat lebih mengatur pemberian asuhan keperawatan setiap perawat yang dinas setiap shifnya dan perawat juga dapat memberikan waktu dan meningkatkan kualitas asuhan keperawatan yang diberikan kepada pasien.

Penelitian ini menunjukkan tidak ada hubungan antara kepemimpinan dengan tingkat burnout pada perawat. Hal ini dikarenakan perawat mempersepsikan bahwa pengawasan yang dilakukan oleh kepala ruangan sudah baik dan kepala ruangan selalu memberikan motivasi, pengarahan dan petunjuk yang jelas kepada perawat. Perawat juga merasa senang dengan perlakuan kepala ruangan dan kepala ruangan dapat menciptakan komunikasi yang baik dengan bawahan. Hasil penelitian ini bertentangan dengan penelitian NIOSH (Ghadampour et al., 2016), yang menyebutkan bahwa tidak adanya atau kurangnya kontrol dalam tugas (supervisi) dari atasan (khususnya pengawasan dari supervisor, kepala ruangan atau pengawasan dari manajemen keperawatan yang lebih tinggi) dapat menjadi salah satu penyebab dan memicu terjadinya burnout bagi perawat. Namun penelitian ini sesuai dengan penelitian yang dilakukan oleh Wirati dkk (Wirati et al., 2020), yang mengatakan bahwa ada hubungan positif antara supervisi klinis kepala ruangan dengan kepuasan kerja perawat pelaksana. Berdasarkan hasil analisis regresi logistic penelitian ini menyimpulkan bahwa yang paling dominan berhubungan dengan tingkat burnout pada perawat adalah variabel reward dengan OR 2.718 artinya perawat yang tidak puas dengan reward berpeluang 2,718 kali mengalami burnout dibandingkan dengan perawat yang puas dengan reward. Hal ini menunjukkan bahwa dengan reward, perawat akan senantiasa termotivasi dan percaya diri untuk mencari prestasi serta mengembangkan dirinya agar bisa menampilkan pekerjaan sebaik-baiknya. Perawat yang merasa bahwa kontribusinya diperhatikan akan merasakan kepuasan dan perawat yang mengalami kepuasan akan bertahan ditempatnya oleh karena itu kontribusi perawat terhadap pelaksanaan dan pengembangan organisasi pada akhirnya akan meningkatkan kepuasan terhadap organisasi dan akan sangat berdampak positif terhadap peningkatan kinerja perawat sehingga tidak mudah mengalami burnout.

\section{KESIMPULAN}

Dari hasil penelitian ini dapat disimpulkan bahwa variabel organisasi, reward dan SDM adalah faktor determinan terjadinya burnout pada perawat di RSUD Lamaddukkelleng Kabupaten Wajo dan faktor yang paling berpengaruh terhadap kejadian burnout pada perawat adalah reward.

\section{SARAN}

Manajemen rumah sakit sebaiknya mengatur sistem pemberian reward secara jelas dan disesuaikan dengan kinerja dan prestasi perawat serta mengawasi implementasinya supaya memotivasi perawat meningkatkan kinerjanya.

Selain Itu, manajemen rumah sakit sebaiknya membuat standar pemberian insentif berdasarkan posisi, tingkat pendidikan, resiko kerja, lama kerja dan lain-lain, serta melakukan pemberdayaan SDM melalui pendidikan/pelatihan, promosi dan mutasi.

\section{DAFTAR PUSTAKA}

Anik, S. (2013). Faktor Yang Berhubungan Dengan Turnover Intentions Perawat Di Rumah Sakit Ibnu Sina YW-UMI Makassar. Akademi Keperawatan Justitia.

Asi, S. P. (2016). Pengaruh Iklim Organisasi dan Burnout terhadap Kinerja Perawat RSUD dr. Doris Sylvanus Palangka Raya. Jurnal Aplikasi Manajemen, 11(3), 515-523.

Avila, J., Rapp, R., Dunbar, S., \& Jackson, A. T. (2021). Burnout and Worklife in Disaster Restoration: Maslach Burnout Inventory and Areas of Worklife Survey. Journal of Construction Engineering and Management, 147(2), 4020171.

Eliyana, E. (2018). Faktor-Faktor yang Berhubungan dengan Burnout Perawat Pelaksana di Ruang Rawat Inap RSJ Provinsi Kalimantan Barat. Jurnal Administrasi Rumah Sakit Indonesia, 2(3).

Ghadampour, E., Farhadi, A., \& Naghibeiranvand, F. (2016). The Relationship Among Academic Burnout, Academic Engagement and Performance of Students of Lorestan University of Medical Sciences. Research in Medical Education, 8(2), 60-68.

Grigor, I. (2018). Promoting Leadership by Education. Illuminating the Diversity of Cancer and Palliative Care Education, 293-305.

Hidayat, I., Sutopo, S., \& Prasetiawan, Y. (2021). Hubungan Motivasi Kerja Perawat dengan Kecenderungan Mengalami Burnout pada Perawat di Ciputra Hospital. HUMANIS (Humanities, Management and Science Proceedings), 1(2).

Kristianto, D., \& Santoso, A. (2019). Hubungan Pemberian Reward Ucapan Terima Kasih dengan Kedisiplinan Waktu Saat Mengikuti Timbang Terima Perawat Ruang Bedah Pada RS Negeri di Semarang. Jurnal Manajemen Keperawatan, 1(2).

Kurnia, E., Damayanti, N. A., \& Nursalam, N. (2018). Formula Penghitungan Tenaga Keperawatan Modifikasi FTE dengan Model Asuhan Keperawatan Profesional Tim. Jurnal Ners, 6(1), 11-20.

Lasebikan, V. O., \& Oyetunde, M. O. (2017). Burnout Among Nurses in A Nigerian General Hospital: Prevalence and Associated Factors. International Scholarly Research Notices, 2017.

Leiter, M. P., \& Maslach, C. (2016). Latent Burnout Profiles: A New Approach to Understanding the Burnout Experience. Burnout Research, 3(4), 89- 
100.

Lumbanraja, P., \& Nizma, C. (2016). Pengaruh Pelatihan dan Karakteristik Pekerjaan Terhadap Prestasi Kerja Perawat di Badan Pelayanan Kesehatan Rumah Sakit Umum Daerah Langsa. Jurnal Manajemen Dan Kewirausahaan, 12(2), pp-142.

Rahayu, S., \& Dewi, E. (2019). Hubungan Antara Sistem Reward dengan Kinerja Perawat dalam Melaksanakan Asuhan Keperawatan di RSUD Sragen.

Ramdan, I. M., \& Fadly, O. N. (2016). Analisis Faktor yang Berhubungan dengan Burnout pada Perawat Kesehatan Jiwa. Jurnal Keperawatan Padjadjaran, 4(2).

Suryani, D., \& Wulandari, Y. (2019). Hubungan antara Beban Kerja, Stres Kerja dan Tingkat Konflik dengan Kelelahan Kerja Perawat di Rumah Sakit Islam Yogyakarta PDHI Kota Yogyakarta. Kes Mas: Jurnal Fakultas Kesehatan Masyarakat Universitas Ahmad Daulan, 3(3), 24895.

Thyer, L., Simpson, P., \& Nugteren, B. Van. (2018). Burnout in Australian Paramedics. International Paramedic Practice, 8(3), 48-55.

Wardah, W., \& Tampubolon, K. (2021). Faktor-Faktor yang Berhubungan dengan Kejadian Burnout Perawat di Rumah Sakit Santa Maria Pekanbaru. Jurnal Kesehatan Medika Saintika, 11(1), 74-84.

Wardana, N., Ernawaty, J., \& Lestari, W. (2017). Hubungan Pemberian Insentif Terhadap Motivasi Kerja Perawat Di Instalasi Rawat Inap (IRNA) Medikal RSUD Arifin Achmad Pekanbaru. Jurnal Ners Indonesia, 1(2), 41-48.

Wirati, N. P. R., Wati, N. M. N., \& Saraswati, N. L. G. I. (2020). Hubungan Burnout Dengan Motivasi Kerja Perawat Pelaksana. Jurnal Kepemimpinan Dan Manajemen Keperawatan, 3(1), 8-14.

Anik, S. (2013). Faktor Yang Berhubungan Dengan Turnover Intentions Perawat Di Rumah Sakit Ibnu Sina YW-UMI Makassar. Akademi Keperawatan Justitia.

Asi, S. P. (2016). Pengaruh Iklim Organisasi dan Burnout terhadap Kinerja Perawat RSUD dr. Doris Sylvanus Palangka Raya. Jurnal Aplikasi Manajemen, 11(3), 515-523.

Avila, J., Rapp, R., Dunbar, S., \& Jackson, A. T. (2021). Burnout and Worklife in Disaster Restoration: Maslach Burnout Inventory and Areas of Worklife Survey. Journal of Construction Engineering and Management, 147(2), 4020171.

Eliyana, E. (2018). Faktor-Faktor yang Berhubungan dengan Burnout Perawat Pelaksana di Ruang Rawat Inap RSJ Provinsi Kalimantan Barat. Jurnal Administrasi Rumah Sakit Indonesia, 2(3).

Ghadampour, E., Farhadi, A., \& Naghibeiranvand, F. (2016). The Relationship Among Academic Burnout, Academic Engagement and Performance of Students of Lorestan University of Medical Sciences. Research in Medical Education, 8(2),
60-68.

Grigor, I. (2018). Promoting Leadership by Education. Illuminating the Diversity of Cancer and Palliative Care Education, 293-305.

Hidayat, I., Sutopo, S., \& Prasetiawan, Y. (2021). Hubungan Motivasi Kerja Perawat dengan Kecenderungan Mengalami Burnout pada Perawat di Ciputra Hospital. HUMANIS (Humanities, Management and Science Proceedings), 1(2).

Kristianto, D., \& Santoso, A. (2019). Hubungan Pemberian Reward Ucapan Terima Kasih dengan Kedisiplinan Waktu Saat Mengikuti Timbang Terima Perawat Ruang Bedah Pada RS Negeri di Semarang. Jurnal Manajemen Keperawatan, 1(2).

Kurnia, E., Damayanti, N. A., \& Nursalam, N. (2018). Formula Penghitungan Tenaga Keperawatan Modifikasi FTE dengan Model Asuhan Keperawatan Profesional Tim. Jurnal Ners, 6(1), 11-20.

Lasebikan, V. O., \& Oyetunde, M. O. (2017). Burnout Among Nurses in A Nigerian General Hospital: Prevalence and Associated Factors. International Scholarly Research Notices, 2017.

Leiter, M. P., \& Maslach, C. (2016). Latent Burnout Profiles: A New Approach to Understanding the Burnout Experience. Burnout Research, 3(4), 89100.

Lumbanraja, P., \& Nizma, C. (2016). Pengaruh Pelatihan dan Karakteristik Pekerjaan Terhadap Prestasi Kerja Perawat di Badan Pelayanan Kesehatan Rumah Sakit Umum Daerah Langsa. Jurnal Manajemen Dan Kewirausahaan, 12(2), pp-142.

Rahayu, S., \& Dewi, E. (2019). Hubungan Antara Sistem Reward dengan Kinerja Perawat dalam Melaksanakan Asuhan Keperawatan di RSUD Sragen.

Ramdan, I. M., \& Fadly, O. N. (2016). Analisis Faktor yang Berhubungan dengan Burnout pada Perawat Kesehatan Jiwa. Jurnal Keperawatan Padjadjaran, 4(2).

Suryani, D., \& Wulandari, Y. (2019). Hubungan antara Beban Kerja, Stres Kerja dan Tingkat Konflik dengan Kelelahan Kerja Perawat di Rumah Sakit Islam Yogyakarta PDHI Kota Yogyakarta. Kes Mas: Jurnal Fakultas Kesehatan Masyarakat Universitas Ahmad Daulan, 3(3), 24895.

Thyer, L., Simpson, P., \& Nugteren, B. Van. (2018). Burnout in Australian Paramedics. International Paramedic Practice, 8(3), 48-55.

Wardah, W., \& Tampubolon, K. (2021). Faktor-Faktor yang Berhubungan dengan Kejadian Burnout Perawat di Rumah Sakit Santa Maria Pekanbaru. Jurnal Kesehatan Medika Saintika, 11(1), 74-84.

Wardana, N., Ernawaty, J., \& Lestari, W. (2017). Hubungan Pemberian Insentif Terhadap Motivasi Kerja Perawat Di Instalasi Rawat Inap (IRNA) Medikal RSUD Arifin Achmad Pekanbaru. Jurnal Ners Indonesia, 1(2), 41-48. 
Wirati, N. P. R., Wati, N. M. N., \& Saraswati, N. L. G. I. (2020). Hubungan Burnout Dengan Motivasi Kerja Perawat Pelaksana. Jurnal Kepemimpinan Dan Manajemen Keperawatan, 3(1), 8-14. 